Хомич Іванна

викладач кафедри вікової та педагогічної психології Рівненського державного гуманітарного університету http://orcid.org/0000-0001-8930-6572. DOI https://doi.org/10.35619/prap_rv.vi14.173

\title{
ВІКОВІ ОСОБЛИВОСТІ ПРОЯВУ ОСОБИСТІСНИХ ХАРАКТЕРИСТИК МОЛОДШИХ ШКОЛЯРІВ
}

Анотація. Стаття присвячена дослідженню проблеми вікових особливостей прояву моральних характеристик молодших школярів. В ході здійснення експериментальної роботи підтвердилася гіпотеза про ймовірний вплив означеної групуючої змінної (віку) на рівень вираженості інтегральних особистісних факторів молодших иколярів, а саме факторів «морально-иіннісного відношення» та «иіннісного відношення до справ, обов'язків та інших людей». Емпіричне дослідження вікових особливостей прояву особистісних характеристик молодших школярів дає змогу констатувати факт накопичення досвіду моральної поведінки 3 віком. Вікова динаміка зміни середніх значень вираженості у молодших школярів особистісних факторів «ціннісного відношення до справ, обов'язків та інших людей» та «морально-ціннісного відношення» має лінійний характер. У період від 6-ти до 9-ти років особистісні характеристики молодших школярів виходять на якісно новий рівень.

Ключові слова: молодший школяр, особистісні характеристики, особистісні фактори, моральні норми, морально-ціннісне відномення, ціннісне відношення до справ, вікова динаміка.

Постановка проблеми. Актуальною бачимо проблему вікових особливостей прояву моральних характеристик молодших школярів. Тому наше дослідження спрямоване на перевірку гіпотези про ймовірний вплив означеної групуючої змінної (віку) на рівень вираженості інтегральних особистісних факторів молодших школярів, а саме факторів «морально-ціннісного відношення»; «особистісного самоствердження»; «ціннісного відношення до справ, обов'язків та інших людей»; «емоційно-ціннісної направленості»; «особистісного самоконтролю»; «відкритості до світу».

Аналіз останніх досліджень 3 проблеми. Процес формування системи цінностей має свою специфіку на кожному віковому етапі розвитку особистості, що і необхідно враховувати у педагогічному процесі. Тому для того, щоб з'ясувати стан сформованості таких факторів як «морально-ціннісне відношення», «особистісне самоствердження», «ціннісне відношення до справ, обов'язків та інших людей», «емоційно-ціннісна направленість», «особистісний самоконтроль», «відкритість до світу» у молодших школярів, необхідно знати закономірності їх вікового розвитку, у чому в значній мірі допомагають думки і висновки видатних психологів. Сучасне бачення та методологічні підходи щодо виховання ціннісних ставлень у молодших школярів відображено у працях Корнєва, 1995; Мухіної, 2004; Орбан-Лембрик, 2004. Психологічні положення про закономірності розвитку дітей молодшого шкільного віку знаходимо у працях Беха, 2009, Мухіної, 2004. Моральні особливості молодших школярів досліджували Мишакова, 2010 та Павелків, 2015. У сучасних наукових дослідженнях розкриваються психологічні механізми формування моральної поведінки. Прогресивні автори зазначають, що визначальним у вихованні $\epsilon$ не зміст моральної вимоги, а психологічна організація дитини як суб'єкта діяльності. Тому основою формування ціннісного ставлення у молодшого школяра $є$ його діяльність та спілкування. Підтримуємо думку Порохняк про те, що необхідною умовою становлення особистості дитини $\epsilon$ розвиток моральних якостей, почуттів і накопичення форм моральної поведінки, що стрімко розвивається саме в період від 6-7 до 9-10 років (2014, с. 393).

Саме емпіричне дослідження вікових особливостей прояву особистісних характеристик молодших школярів дає змогу констатувати факт накопичення досвіду моральної поведінки 3 віком.

Метою статті є здійснення аналізу прояву особистісних характеристик молодших школярів 
у відповідності з їхніми віковими особливостями на основі компонентних складових факторної структури особистості (інтегральних особистісних факторів) з урахуванням наукових підходів до вказаної проблеми. Згідно із сформульованою метою нашими завданнями є: аналіз останніх публікацій із теми нашої роботи та здійснення емпіричного аналізу вказаної проблеми.

Виклад основного матеріалу дослідження. Молодший шкільний вік $є$ важливим у становленні особистості дитини, бо саме тоді закладаються основи особистісного розвитку учнів початкової школи. Віковими особливостями дітей 1 - 4 класів можна вважати: незначний соціальний та моральний досвід, підвищену емоційність, вразливість і водночас пластичність до морально-етичних впливів, імпульсивність та безпосередність поведінки дитини, бажання постійно розширювати коло спілкування. Тому узгодження поведінки та усвідомлення моральних явищ життя характеризуються емоційними узагальненнями, аналізом ситуацій та вчинків, які відповідають загальнолюдським етичним цінностям. Розрив між знаннями моральних принципів і відповідною поведінкою - найхарактерніша властивість дитини цього віку. Подальшого розвитку набуватимуть такі моральні почуття: провини, сорому, обов'язку, відповідальності, справедливості, власної гідності, сумління.

Дослідження проводилось на базі Рівненської гімназії «Гармонія», Рівненської класичної гімназії «Престиж» (м. Рівне), Луцьких загальноосвітніх шкіл I-III ступенів №5 і №8 (м. Луцьк) та Тернопільської загальноосвітньої школи I-III ступенів №19 (м. Тернопіль). Досліджуваними стали учні перших-четвертих класів у кількості 189 осіб.

У попередніх статтях нами було визначено особистісні характеристики молодших школярів та здійснено їх факторизацію з метою верифікації факторної моделі соціально-психологічної компетентності учнів молодших класів у сфері нормовідповідності власної поведінки. Структурними компонентами факторної моделі ми визначили інтегральні (латентні) особистісні фактори, які детермінують змістовий характер і специфіку (рівень розвитку) уявлень молодших школярів про нормовідповідність власної поведінки. Результати факторного аналізу дозволили виділити факторну модель особистісних характеристик молодших школярів. В структуру даної моделі увійшло шість інтегральних факторів: «морально-ціннісного відношення»; «особистісного самоствердження»; «ціннісного відношення до справ, обов'язків та інших людей»; «емоційноціннісної направленості»; «особистісного самоконтролю»; «відкритості до світу». Специфічні особливості вказаних інтегральних особистісних факторів молодших школярів виступають особистісними предикторами розвитку їх соціально-психологічної компетентності у сфері нормовідповідності власної поведінки.

У цьому матеріалі висвітлемо результати порівняльного аналізу показників вираженості інтегральних особистісних факторів молодших школярів, згрупованих у категорії на підставі вікового критерію. Зазначимо, що в якості порівнюваних показників вираженості інтегральних особистісних факторів молодших школярів було використано середні значення їх факторних оцінок, попередньо обчислених на заключному етапі факторизації емпіричних даних. В даному випадку факторна оцінка являє собою кількісну міру вираженості інтегрального особистісного фактору, представлену в одиницях стандартного відхилення, тому середнє значення фактору знаходитиметься в межах від -3 до +3 . Таким чином, в ході реалізації даного етапу дослідження перевірялась гіпотеза про ймовірний вплив означеної групуючої змінної (віку) на рівень вираженості інтегральних особистісних факторів молодших школярів. Отож, перейдемо до аналізу та змістової інтерпретації отриманих результатів. При подальшій інтерпретації виявлених тенденцій залишимо поза увагою детального аналізу ті відмінності у середніх значеннях вираженості особистісних факторів досліджуваних, які не мають статистично значущого характеру. Також, враховуючи характер отриманих результатів - середні значення факторних оцінок, представлених в одиницях стандартного відхилення, - узагальнення табличних даних коректно буде провести 3 використанням результатів вивчення достовірних відмінностей у середніх значеннях вираженості особистісних факторів досліджуваних.

Отож, залежно від віку середні значення вираженості особистісних факторів молодших школярів розподілилися наступним чином (див. табл. 1). 3 огляду на табличні дані, можна стверджувати, що достовірні відмінності у середніх значеннях вираженості особистісних факторів 
у досліджуваних різного віку виявлені у відношенні лише «ціннісного відномення до справ, обов'язків та інших людей» $(\mathrm{p}<0,05)$.

Таблиия 1

Відмінності у середніх значеннях вираженості особистісних факторів досліджуваних залежно від віку

\begin{tabular}{|c|c|c|c|c|c|c|c|}
\hline \multirow[t]{2}{*}{ Вік } & \multirow{2}{*}{$\begin{array}{c}\text { Категорія } \\
\text { показників }\end{array}$} & \multicolumn{6}{|c|}{ Кількісні показники особистісних факторів } \\
\hline & & $\begin{array}{l}\text { морально- } \\
\text { ціннісне } \\
\text { відношення }\end{array}$ & $\begin{array}{c}\text { особистісне } \\
\text { самостверджен } \\
\text { ня }\end{array}$ & $\begin{array}{c}\text { ціннісного } \\
\text { відношення до } \\
\text { справ, обов'язків } \\
\text { та інших людей }\end{array}$ & $\begin{array}{c}\text { емоційно- } \\
\text { ціннісної } \\
\text { направленості }\end{array}$ & $\begin{array}{l}\text { особистісного } \\
\text { самоконтролю }\end{array}$ & $\begin{array}{l}\text { відкритості } \\
\text { до світу }\end{array}$ \\
\hline \multirow{2}{*}{$\begin{array}{l}6-7 \\
\text { років }\end{array}$} & $\begin{array}{l}\text { Середнє } \\
\text { значення }\end{array}$ & 0,0370 & 0,1449 & $-0,2619$ & $-0,1246$ & 0,1106 & 0,0039 \\
\hline & $\begin{array}{l}\text { Станд. } \\
\text { відхилення }\end{array}$ & 0,9282 & 0,9913 & 1,0402 & 0,8826 & 1,0152 & 1,1839 \\
\hline \multirow{2}{*}{8 років } & $\begin{array}{l}\text { Середнє } \\
\text { значення }\end{array}$ & 0,2412 & $-0,0567$ & $-0,0760$ & 0,1085 & $-0,2804$ & $-0,0655$ \\
\hline & $\begin{array}{l}\text { Станд. } \\
\text { відхилення }\end{array}$ & 1,0270 & 0,9765 & 1,0180 & 0,9608 & 0,8637 & 1,0545 \\
\hline \multirow{2}{*}{9 років } & $\begin{array}{l}\text { Середнє } \\
\text { значення }\end{array}$ & 0,0784 & $-0,0153$ & 0,1825 & 0,0337 & $-0,0058$ & 0,1559 \\
\hline & $\begin{array}{l}\text { Станд. } \\
\text { відхилення }\end{array}$ & 0,8869 & 1,0978 & 0,9912 & 1,1356 & 1,1048 & 0,9467 \\
\hline \multirow{2}{*}{$\begin{array}{l}10 \\
\text { років }\end{array}$} & $\begin{array}{l}\text { Середнє } \\
\text { значення }\end{array}$ & $-0,3354$ & $-0,0660$ & 0,1836 & $-0,0189$ & 0,1626 & $-0,0991$ \\
\hline & $\begin{array}{l}\text { Станд. } \\
\text { відхилення }\end{array}$ & 1,1088 & 0,9722 & 0,9299 & 1,0374 & 0,9949 & 0,8433 \\
\hline \multicolumn{2}{|c|}{$\begin{array}{l}\text { Рівень статистичної } \\
\text { значущості }\end{array}$} & 0,127 & 0,378 & 0,034 & 0,907 & 0,395 & 0,452 \\
\hline
\end{tabular}

Детальний аналіз табличних даних дозволяє констатувати, що вікова динаміка зміни середніх значень вираженості у молодших школярів особистісного фактору «ціннісного відношення до справ, обов'язків та інших людей» має лінійний характер. Так, очевидним є те, що означений фактор найвищих середніх значень досягає у найстаршій віковій категорії молодших школярів (10 років), демонструючи пік найнижчих середніх значень у наймолодшій віковій категорії досліджуваних (6-7 років). Це означає, що значення усіх психологічних шкал, що структурно і змістовно визначають специфіку даного інтегрального особистісного фактору, лінійно зростають на протязі усього періоду молодшого школярства. Зокрема, у найстарших молодших школярів у порівнянні з наймолодшими представниками даного віку спостерігаються достовірно вищі показники вираженості таких психологічних шкал, як «ефективність у справах», «організаторські здібності», «взаємовідносини 3 іншими дітьми», «працелюбність», «підприємливість» і «практичність». Фактично, можна стверджувати, що 3 віком у молодших школярів ставлення і відношення до праці, діяльності (наприклад, навчальної), справ, обов'язків та інших людей стає більш відповідальним та утилітарним, набуваючи усвідомленого і ціннісного характеру. Перейдемо до змістової інтерпретації виявленої закономірності.

Павелків (2015) стверджує, що центральним моментом молодшого шкільного віку $є$ усвідомлення свого нового місця у системі суспільних відносин. На цьому етапі у молодшого школяра формується ядро особистості, (моральні почуття, цінності, переживання), відбувається набуття досвіду моральної поведінки, він стає активним учасником у житті колективу, у виборі доручень, у виконанні улюблених справ. Процес залучення дітей до моральних цінностей сенситивний, оскільки саме в цей період закладаються основи світогляду і моральності, усвідомлюється необхідність відповідних якостей, визначаються взірці, формується моральна поведінка, які стануть основою світосприйняття молодої людини в майбутньому. Мухіна (2004) називає основні види потреб дітей цього віку, серед яких: потреба в емоційному контакті; в дружбі, товариськості, у повазі особистості, самоповазі. На думку дослідниці, саме в цей період 
розвиваються і зміцнюються внутрішні етичні інстанції, формуються моральні мотиви, більш усвідомленими стають почуття провини, сорому, обов'язку, відповідальності, емпатії тощо.

В молодших школярів виникає особливе новоутворення - відносно стійкі форми поведінки і діяльності, які в майбутньому становитимуть основу формування характеру. У вчинках дітей наприкінці другого року навчання вже проглядається позиція у ставленні до того, що їх оточує. Розвиваються і змінюються внутрішні етичні інстанції, формуються моральні мотиви поведінки; розвивається здатність співпереживати, співчувати, а отже, i співдіяти 3 дорослими та однолітками. Молодший шкільний вік (за Бехом, 2009) виявляється сприятливим щодо виховання у дитини фундаментального для іiї морального розвитку новоутворення. Формування особистісних якостей молодшого школяра значною мірою визначається реалізацією у виховному процесі діяльнісного підходу, згідно з яким моральні правила і норми дитина засвоює активно, в процесі діяльності та спілкування з дорослими, однолітками, старшими та молодшими дітьми. Виховання молодших школярів здійснюється у процесі навчально - пізнавальної діяльності як провідної шляхом внесення ціннісних складових у зміст навчальних предметів, відведення належного місця «спільно взаємодіючій діяльності» як на уроках, так і в позаурочний час; гуманізації взаємин у системах «учитель - учень», «учень - учень»; використання вчителем демократичного стилю спілкування з учнями; створення умов для творчої самореалізації кожної особистості. Важливим $\epsilon$ особистісно орієнтований підхід у вихованні молодших школярів, оскільки для дітей цієї вікової групи характерна особлива сенситивність до морально-етичних впливів, а надто сприйняття норм культурної поведінки, спілкування, мовного етикету, культури взаємовідносин. Головне завдання вчителя - створювати і використовувати у шкільному житті ситуації, в яких знання і дії були б злиті та дозволили б фіксувати динаміку духовно-морального розвитку дитини, суть якого полягає у вмінні дитини реалізувати свої здібності до практичної діяльності. Вчитель має допомогти дитині розвиватись від елементарних навичок поведінки до більш високого рівня, для якого необхідні самостійність у прийнятті рішень і моральний вибір. Детальний аналіз даних дозволяє констатувати, що вікова динаміка зміни середніх значень вираженості у молодших школярів особистісних факторів «ціннісного відношення до справ, обов'язків та інших людей» та «морально-ціннісного відношення» має лінійний характер. У період від 6-ти до 9-ти років особистісні характеристики молодших школярів виходять на якісно новий рівень.

Висновки і перспективи подальших розвідок. Таким чином, у молодших школярів відповідно до їх вікових особливостей формуються особистісний ціннісний фактор «ціннісного відношення до справ, обов'язків та інших людей» та фактор «морально-ціннісного відношення». Вимоги соціуму актуалізують виховання цих ціннісних ставлень. Подальше дослідження буде спрямоване на вивчення стану сформованості проблем статево-специфічних та соціальних особливостей прояву особистісних характеристик молодших школярів.

\section{СПИСОК ПОСИЛАНЬ}

Бех, І. Д. (2009) Основні орієнтири виховання учнів 1-12 класів загальноосвітніх навчальних закладів Украӥни: програма. Академія педагогічних наук України. Тернопіль: Навчальна книга Богдан.

Бююль, А. (2005). SPSS: искусство обработки информации. Анализ статистических данных и восстановление скрытых закономерностей. ДиаСофтЮп.

Киричок, В. А. (2004) Гуманне ставлення до дитини: методологічний посібник [для вчителів]. Київ: Інфодрук.

Мишакова, Г. А. (2010) Психологические особенности нравственности младших школьников, воспитывающихся в различных сочиально-педагогических условиях (Автореф. дис. канд. психол. наук). Самара.

Мухина, В. С. (2004) Возрастная психология: феноменология развития, детство, отрочество. Москва: Академия.

Орбан-Лембрик, Л. Е. (2004) Соиіальна психологія. Київ: Либідь.

Павелків, Р .В. (2015) Розвиток моральної свідомості та самосвідомості в молодиому шкільному віuіi (Дис. доктора психол. наук). Рівненський державний гуманітарний університет. Рівне. 
Порохняк, Д. С. (2014) Вікові особливості морального розвитку молодших школярів. Збірник наукових праць К-ПНУ імені Івана Огієнка Інституту психології імені Г.С. Костюка, 25, 393-403.

\section{REFERENCES}

Bekh, I. D. (2009) Key guiding principles of pupils' education at the $1^{\text {st }}-12^{\text {th }}$ forms in Ukrainian general educational institution: program. The Academy of Pedagogical Sciences of Ukraine. Ternopil: Course book Bohdan. [in Ukrainian].

Biuiul, A. (2005). SPSS: iskusstvo obrabotki informatsyi. Analiz statisticheskikh dannykh i vosstanovleniie skrytykh zakonomernostei [Information processing art. Statistical data analysis and hidden patterns restoration] DiaSoftYup.

Kyrychok, V. A. (2004) Human treatment to the child: methodological textbook [for teachers]. Kyiv: Infoprint. [in Ukrainian].

Mishakova, H. A. (2010) Psikholohicheskiie osobennosti nravstvennosti mladshykh shkolnikov, vospityvaiushchykhsia $\mathrm{v}$ razlichnykh sotsialno-pedahohicheskikh uslovyiakh (dys. na soiskaniie uch. stepeni kand. psykhol. nauk) [Morality psychological features of junior schoolchildren who are brought up in different social and pedagogical conditions (thesis for a candidate degree in psychological sciences)] Samara. [in Russian].

Mukhina, V. S. Vozrastnaia psykholohiia: fenomenolohiia razvitiia, detstvo, otrochestvo [Developmental psychology: development phenomenology, childhood, adolescence] Moskva: Akademiia. [in Russian].

Orban-Lembryk, L. E. (2004) Sotsialna psykholohiia [Social psychology] Kyiv: Lybid. [in Ukrainian].

Pavelkiv, R.V. (2015) Rozvytok moralnoi svidomosti ta samosvidomosti v molodshomu shkilnomu vitsi (Dys. doktora psykhol. nauk) [Moral consciousness and self-consciousness development in junior schoolchild's age (psychological sciences doctor thesis)] Rivnenskyi derzhavnyi humanitarnyi universytet. Rivne. [in Ukrainian].

Porokhniak, D. S. (2014) Vikovi osoblyvosti moralnoho rozvytku molodshykh shkoliariv [Age peculiarities of junior schoolchildren moral development]. Zbirnyk naukovykh prats K-PNU imeni Ivana Ohiienka Instytutu psykholohii imeni H.S. Kostiuka, 25, 393-403 [in Ukrainian].

\section{AGE PECULIARITIES OF PRIMARY SCHOOLCHILDREN'S PERSONAL CHARACTERISTICS EXPRESSION}

Ivanna Khomych

Lecturer of the

Department of Developmental and Educational Psychology Rivne State University of the Humanities http://orcid.org/0000-0001-8930-6572.

DOI https://doi.org/10.35619/prap_rv.vi14.173

Abstract. The study is concerned with the research the age peculiarities issue of primary schoolchildren's moral characteristics expression. During the experimental work implementation it has been confirmed the hypothesis dealing with the probable influence of the mentioned grouping variable (age) on the expression level of primary schoolchildren's integral personal factors meaning factors of moral-and values-based attitude and values-based attitude to the affairs, duties, and other people. Empirical research of age peculiarities of primary schoolchildren's personal characteristics expression gives the possibility to establish the fact of gaining the experience concerning with moral behavior with the age. The author points out that the age dynamics of average values change dealing with the personal factors expression of values-based attitude to affairs, duties, and other people, moral-and values-based attitude presented by primary schoolchildren has got the linear character. Primary schoolchildren's personal characteristics reach whole new level during the period from six to nine years.

Keywords: primary schoolchild, personal characteristics, personal factors, moral standards, moral-and values-based attitude, values-based attitude to the affairs, age dynamics. 